\title{
Improvement of Lecturer Competency in Order to Reach Superior Human Resources (Study of Lecturer Competency in Universitas Muhammadiyah Bandung)
}

\author{
$1^{\text {st }}$ Setiadin \\ Lecturer Public Administration \\ Faculty of Social Science Humanities \\ Universitas Muhammadiyah Bandung \\ Indonesia \\ *doktor.dinsetiadin@umbandung.ac.id
}

\author{
$2^{\text {nd }}$ Rohida \\ Lecturer Public Administration \\ Faculty of Social Science Humanities \\ Universitas Muhammadiyah Bandung \\ Indonesia
}

Abstract-Competence is essentially a product of thinking activities, meaning competencies that are realized in the human mind as a result of thinking activities. Lecturers as educators are required to have several competencies, which include pedagogical, professional, social and personality competencies. Lecturers become important factors in relation to the implementation of coaching, development and decision making in order to realize the vision, mission of higher education. To realize quality universities, the improvement of lecturer competence cannot be ignored in an organization such as a university, namely by paying attention to the development of lecturers, especially in improving technical, theoretical, conceptual, and moral abilities for the purpose of giving birth to good and professional lecturer performance, universities must also have professional development of lecturers who refer to the Tridharma of Higher Education. The approach used in this research is a qualitative approach with descriptive methods, data collection techniques are done through interviews, observation, and study documentation. The results of this study produce models and concepts of lecturer competency improvement with a strong focus on overall human resource management strategies, moreover that the existence of human resources such as skills and knowledge is a must to be mastered then coupled with reliable behaviors including social skills will be a qualification qualification requirement that every human resource must possess to be able to compete and take part in the era of the industrial revolution 4.0. Increasing the competence of industry era 4.0 lecturers is a necessity that should be designed by each individual, family, government, and community, especially in the world of education and organizations.

Keywords - competency, human resources management

\section{INTRODUCTION}

In the development of the global world today has made education as primary needs and cannot be considered as secondary needs. Along with the changing needs, more and more educational institutions are providing education for the community, of course, with the quality of each graduate institution that is not the same, and this quality is very dependent on the quality of these institutions, including Higher Education institutions. The vision and mission of Higher Education in Indonesia is centered on optimizing contributions to efforts to improve the quality of the nation, the development of science, technology, culture, and national identity as a whole. According to Murniati (2008: 21)

"Education is one of the important factors in achieving superior and quality Human Resources, education is believed to contribute positively to the progress of development, both short term, medium term and long term". So as to prepare superior human resources who are able to answer the challenges of the new century with quality education. For this reason, it is important that efforts are made in improving the quality of higher education and on an ongoing basis, especially by clarifying the vision and orientation, that universities are public institutions that provide educational services for the community, to be able to produce superior, high quality human resources, has expertise and professional competence in facing global competition. Higher education as a provider of higher education must appear as an important and reliable part in the development of the nation's progress and civilization. Besides that, higher education has a national mission and is the infrastructure to produce graduates who are superior, qualified and virtuous nation leaders.

One of the most important components in the process of higher education is Human Resources (HR) in this case the lecturer, who is also assisted by other components such as facilities, infrastructure and other infrastructure. HR development in tertiary institutions must always be done to improve the knowledge and skills possessed by the lecturer staff, because lecturers are the main element in the higher education process, without the role of lecturers all policies and programs cannot succeed in realizing the nation's 
development in the field of education, because lecturers as an educator has a strategic role. Through efforts to develop and increase the capacity of human resources as educators, it is expected that lecturers can achieve the qualifications and competencies required as professional lecturers.

Lecturers become the main and important factor in relation to the implementation of coaching, development and decision making in order to realize the vision, mission of the tertiary institution, besides it can also be used as an open performance appraisal referring to Higher Education Tridharma which consists of activities: 1) education, 2) research, and 3) community service. Dikti (2007: 2) stipulates: Lecturers are professional educators and scientists with the main task of transforming, developing and disseminating science, technology, and art through education, research and community service. As a professional, lecturers are required to always make innovative and inventive efforts in the field of science for which they are responsible. Lecturers must constantly develop innovative and inventive works that can be achieved through a series of research activities and community service focused. As a consequence of the professionalism of a lecturer in his field, the lecturer must be able to reach the level of competence in the field of science for which he is responsible.

Competence is a set of knowledge, skills and behaviors that must be possessed, internalized, and mastered by lecturers in carrying out their main tasks as demanded by Tridharma of higher education. Nurudin (2006: 1) argues that "The consequences of a lecturer's professional are having a commitment to the professionalism function of a lecturer as: (a) a learning agent; (b) the bearer of science, technology and art; and (c) community service. " In connection with the changing times that are very dynamic, the tertiary institution is obliged to prepare a development program for lecturers in their environment to maintain professionalism and at the same time strengthen their competence in the fields for which they are responsible. Most of the teaching and learning process in higher education is based on the results of research (teaching based research), and it would be better if the research was conducted by the lecturer himself. The results of research conducted by lecturers must be informed, explained, and discussed together, both between lecturers and students, between lecturers and lecturers so that they become interesting and actual topics.

Research and community service activities are inseparable activities in the education process in tertiary institutions that require lecturers not only to teach but also to conduct research and community service. Lecturers who conduct research and community service must be consistent with the field of science or subject that is supported and at the same time be their responsibility. So that research or dedication to the community of lecturers in a tertiary institution influences the quality of the tertiary institution. In this connection Dikti (2006: 1) stipulates "Improving the quality of education in tertiary institutions can be achieved through various means, including improving lecturer competence, increasing curriculum content, improving the quality of learning and evaluating student learning outcomes, providing adequate teaching materials, and providing learning facilities ". Of all these methods, improving lecturer competence and learning quality occupies a very strategic position. Nurudin (2006: 1) argues that a lecturer will not be separated from his 4 (four) basic competencies, namely: (1) pedagogical competence; (2) personality competence; (3) professional competence; and (4) social competence ". Professional competence includes the ability to design, carry out and compile research reports; the ability to develop and disseminate innovations in the fields of science, technology and art; the ability to design, implement and assess community service.

To carry out educational functions in tertiary institutions, educators are needed who have good educational qualifications and competencies. This is in accordance with PPDIKTI 2019 data of 2018 permanent lecturer qualifications, lecturers with S3 education are $14 \%$, S2 77\% and others are 9\%. With lecturers who have higher education and it is hoped that lecturers with S3 education will provide quality improvement, and universities must also have professional development of lecturers that refers to the tridharama of higher education. To realize quality universities, the development of lecturers cannot be ignored in an organization such as a university, namely by paying attention to the development of lecturers, especially in improving technical, theoretical, conceptual, and moral abilities for the purpose of giving birth to good and professional lecturer performance. So far, many universities are still not optimal in making efforts to improve the performance of lecturers, especially in the environment of private universities. This relates to the issue of funds needed in carrying out development activities and improving lecturer performance. In addition, commitments from university leaders are also an obstacle so far. Basically, the process of developing lecturers is the responsibility of all university leaders, each leader ideally always meets the needs of the development of lecturers in an effort to improve performance and professionalism to realize the ideals of the Higher Education that they lead through well-planned development programs.

\section{METHOD}

This study uses a qualitative research method with a descriptive approach, so the emphasis is not based on measurement (statistics), but rather on describing the actual, factual, natural, and holistic about how to increase lecturer competence in order to realize superior human resources (lecturer competency studies in Muhammadiyah University Bandung). Data is collected through literature studies (library research) by examining various information that comes from documents, mass media, journals, and so forth. Then the data analysis is done through data analysis, interpretation of the data to drawing conclusions.

\section{LITERATURE REVIEW}

\section{A. Human Resource Development}

In line with the statement Sergiovanni, et.al, which states that: "Perhaps the most critical difference between the school and most other organizations is the human intensity that characterizes its work. Schools are human organizations in the sense that their products are human 
and their processes require the socializing of humans ". In the process of improving education the important thing is the development of human resources. Where the intensity of the world of education related to humans can be seen as an important difference between educational institutions and other organizations. This shows that the problem of human resources becomes very dominant in the education process, this also means that managing human resources is a very important field in implementing the educational process in higher education institutions. Wherther and Davis, stated that human resources in the context of management are "people who are ready, willing, and able to contribute to organizational goals". Therefore, human resources in an organization including Education organizations improve their performance so that they can contribute to the achievement of goals. Thus, the education human resources referred to here are those that include: (1) teaching staff, consisting of supervisors, examiners, lecturers/lecturers, and trainers; (2) educational functional staff, consisting of inspectors, supervisors, researchers and developers in the field of education, and librarians; (3) educational technical personnel, consisting of laboratory assistants and learning resource technicians; (4) education unit management personnel, consisting of school principals, directors, chairs, chancellors, and leaders of non-school education units; and (5) other staff who deal with managerial or administrative problems in education. Whereas Mulyati, who cites the opinions of Mondy, Noe, and Premeaux stated that HR development includes: (1) training, (2) development, (3) career development, and (4) performance evaluation (performance apprasial). Development includes learning opportunities that aim to further enhance the knowledge and skills needed in the work being undertaken. Development is more focused for the long term. Career development is a formal approach that organizations use to ensure that people with the right qualifications and experience are available when needed.

Human resource development is related to the availability of opportunities and development of learning, making training programs that include planning, organizing, and evaluating these programs.

Another definition of development (development) is representing a future-oriented investment in employees. Development is based on the fact that an employee needs a growing set of knowledge, skills and abilities in order to work well and be successful in positions he has encountered during his career. According to Murti Sumarni and John Soeprihanto, there are two methods of training and development, namely: a. Training (Training). Exercise is an activity to improve the ability of an employee by increasing the ability and skills of employees in carrying out a job. b. Education (Education). Education is an exercise to improve the training of an employee about general knowledge and general economic knowledge, including increased mastery of theory and decision-making skills in dealing with the problems of company organization. The leadership has responsibility for the general policies and procedures needed to implement the training and development program. Therefore, the leadership commitment is very important so that training and development of employees takes place effectively, both from planning,

B. Lecturer Competence

In general, the understanding of teaching staff or lecturers as appropriate mandated in the Law of the Republic of Indonesia Number 14 of 2005 concerning Teachers and Lecturers, Lecturers are professional lecturers and scientists with the main task of transforming, developing and disseminating science, technology and art through education, research and community service. Lecturers have a professional position at a higher education level that is appointed in accordance with statutory regulations. In the process of education in tertiary institutions, lecturers hold a dual task, namely as a teacher and supervisor. As a lecturer, the task is to pour a number of material into students, while as a supervisor, the lecturer is tasked with guiding students so that individuals are creative and independent, both teaching and guiding are the duties and responsibilities of lecturers as professionals. Therefore, the hard task of a lecturer basically can only be carried out by lecturers who have the following competencies:

\section{Personality competence}

Everyone has different personalities, as well as lecturers who have their own personalities to adapt to their work environment. The Directorate General of Higher Education Ministry of National Education (2009: 28) sets limits, namely: "Personality competence is a number of values, commitments, and professional ethics that affect all forms of lecturer behavior towards students, peers, family and society and affect student motivation including professional development". So from the above understanding it can be concluded that personality competence is a behavior of a lecturer who will later become an example for his students and be a motivation for learning for students.

\section{Social Competence}

According to Spencer and Spencer (1993: 36) social competence is: "Character of attitude and behavior or willingness and ability to build cooperation nodes with other people who are relatively stable when facing problems at work that are formed through the synergy between character and self- concept . Internal motivation, and conceptual social knowledge capacity. Social competence is inseparable from the character and attitudes that are inherited by people who are influenced by the social situation at work, the condition of social groups, social tasks and individual circumstances to adapt to various work environment conditions. According to Imam Sugeng (2002: 200) said: "Social competence is the character of attitude and behavior or the willingness and ability to build cooperation nodes with others that are relatively stable when facing problems in the workplace that are formed through the synergy between character, concept self, internal motivation and the capacity of social knowledge ". Furthermore, it can be stated that teaching staff or lecturers who have high social competence are able to build good and stable cooperation when they experience problems in their workplaces. 


\section{Professional Competence}

According to Spencer and Spencer (1993: 73) professional competence is "Mastery of the field of knowledge related to work (can be in the form of techniques, managerial or professional), and motivation to use, develop and share work-related knowledge to others". Then it can be concluded that professional competence is the ability of a lecturer in mastering broad and deep learning material that allows him to guide students to meet the competency standards set out in the National Education Standards.

\section{Pedagogical Competence}

As mandated by PP 19 of 2005, in Irtanto et al., (2010: 3) that: "Pedagogical competence is the ability to manage learners' learning which includes understanding of students, designing and implementing learning, evaluating learning outcomes, and developing student learning. to actualize the various potential possessed ". Pedagogical competence is the backbone of the success of the educational process in higher education. This pedagogical competence is related to good and appropriate teaching methods, so that the learning process can run smoothly and effectively. A lecturer, in addition to having expertise in his scientific field, must also master the theories and teaching techniques and their applications in the learning process in higher education. Capacity building in this field is the main thing in developing professionalism of lecturers (Romli SyZain: 2010) based on what was written (Journal of Humanities Development Vol. 11 No. 1, April 2011).

Lecturers play a central role in learning. for that the quality of education in higher education is determined by the ability possessed by a lecturer in carrying out their duties. Lecturers are the determining factor for the success of education in educational institutions. because the lecturer is central and the source of learning activities. It was further stated that lecturers are a component in improving the quality of education in educational institutions. This shows that the ability or professional competence of a lecturer greatly determines the quality of education.

\section{DISCUSSION}

Lecturers must have the necessary qualifications in conveying their knowledge to students. With competent and qualified lecturers, it will facilitate the delivery of science and technology so that what is conveyed to students can be accepted and developed according to students' abilities with the study of the chosen field of science. In relation to these qualifications, the lecturer always has at least been awarded functional position equals because the higher the functional position the lecturer shows the level of lecturer qualifications, achievements and achievements. Besides that lecturers must also have high discipline, responsibility for the knowledge given to students.

Without any effort to improve the quality of lecturers, fundamental changes to the curriculum and teaching and learning methods, are ineffective. Improving the quality of lecturers needs to start from the recruitment system, improvement of lecturers' abilities, a system of assessing the ability and performance of lecturers, a system of career advancement and welfare improvement. The ability of lecturers includes the ability of the science being taught and the techniques of providing teaching. or the ability to teach, use appropriate learning methods. Besides that, it can be seen from the classification of education (S2 / S3) and the level of academic positions, Management of lecturer quality can be done through improving education to higher strata. A fundamental problem commonly faced by lecturers in continuing their education to S2 / S3 concerns the cost of education and the relevance of scientific disciplines. The management of education is always more concerned with improving the quality of lecturers, by providing adequate funding support in the university's expenditure budget.

Besides that it can be done through increasing seminar activities (local, regional and national), symposiums, discussions, and upgrading and workshops, both at the University itself, as well as at leading universities. Enhancing collaborative activities with agencies, business and industry in relation to the program of linkages and equivalence as an added insight and way of thinking and skills for lecturers. With the synergy between the government, universities and the business / industry world, the imbalance of the quality of university graduates is a shared responsibility that must be borne, the government provides the function of coaching and regulating business / industry to absorb graduates and the university prepares graduates with quality standardization to fill working world.

\section{CONCLUSION}

Based on the research results, it was found that Lecturers must have the qualifications needed to convey their knowledge to students. In addition, lecturers must also have high discipline, responsibility for the knowledge given to their students.

Improving the quality of lecturers needs to start from the recruitment system, increasing the ability of lecturers, the system for assessing the ability and performance of lecturers, systems for enhancing career and increasing welfare, then the ability of lecturers to include lecturers' abilities. the science taught and the technique of giving instruction. or teaching skills, use appropriate learning methods. In addition, it can be seen from the education classification (S2 / S3) and the level of academic position.

The fundamental problems often faced by lecturers in continuing their education to S2 / S3 are related to the cost of education and the relevance of scientific disciplines. The management of education is always more concerned with improving the quality of lecturers, by providing adequate financial support in the university budget.

Increasing collaborative activities with agencies, business and industry in relation to linkage and equality programs as an addition to insight and ways of thinking and skills for lecturers.

\section{ACKNOWLEDGMENT}

By calling on the name of Allah the Most Gracious, Most Loving, we pray and thank God for His presence, who has bestowed His grace, guidance, and hidayah-Nya on us so that we can finish a scientific paper on The $1^{\text {st }}$ Paris Van Java International Seminar (PVJ-IS). This scientific 
paper we have compiled with the maximum and get help from various parties so as to facilitate the making of this paper. To that end we extend our gratitude to all those who have contributed in the making of this paper. Apart from that, we are fully aware that there are still shortcomings in terms of both sentences and grammar. Therefore, with open arms we receive all the suggestions and criticism from our readers so that we can improve this scientific paper. Finally, we hope that the scientific paper on waste and its benefits for the community can provide benefits and inpiration to the readers.

\section{REFERENCES}

[1] Aththaariq, R.M. Mochammad Wispandono, M. Alkirom Wildan. 2014. Effect of Lecturer Competence on Lecturer Performance at Trunojoyo University Madura. Journal of Management and Business Studies Vol 1 No. 1.

[2] Irtanto. Herrukmi Septa R ,. Supriyanta. Widodo Djati Sasongko. 2010. Implementation of Government Regulation No. 19 of 2005 Concerning National Education Standards (Study of the Competency Quality of Human Resource Teachers in Urban High Schools in East Java)

[3] Iman Sugeng. 2002. Measuring and Managing Intellectual Capital. New Paradigm in Human Resource Management. Editor A. Usmara. Amara Books publisher.

[4] Murniati. A.R \& Usman, Nasir. 2008. Strategic Management, the Role of the Principal in Empowerment. Bandung.

[5] Nurudin. 2006. Threatened Professionalism of Lecturers. Suara Merdeka, 4 December.

[6] Romli Sy-Zain. 2011. Journal of Humanities Development Vol. 11 No. April 1st.

[7] Rusmini, Improving the Quality of Higher Education Institutions Through Human Resource Development. file: III C: /Users/HP\%20PC/Downloads/Documents/56567-ID-increasedmutu-lembaga-dendasional-ting.pdf download April 20, 2020

[8] Warmayanti. Strategies to Improve Quality or Quality of Education to Achieve the University of DR. Soetomo / Unitomo Excellent. file: /// C: / Users / HP\% 20PC / Downloads / Documents / ORATION\% 20BOOK (Revised\% 2024\% 20 Jul\% 2017) -1.pdf download on April 20, 2020.

[9] Spencer, Lyle \& Signe M. Spencer.1993. Competence at Work, Models For Superior Performance. Canada: John Wiley \& Sons, Inc.

[10] Law of the Republic of Indonesia Number 14 of 2005 concerning Teachers and Lecturers, Kurata M 1982 Numerical Analysis for Semiconductor Devices (Lexington, MA: Heath)

[11] Yoana Octaviana. 2015. Analysis of Personality, Social, Professional and Pedagogical Competency Profiles of Superior Performance Lecturers (Case Study of Faculty of Business and Management Lecturers at Widyatama University). 2015. https://repository.widyatama.ac.id/xmlui/handle/123456789/5782. file:///C:Users/HP\%20PC/Downloads/Documents/Bab\%202.pdf 